medRxiv preprint doi: https://doi.org/10.1101/2020.08.05.20168872; this version posted August 6, 2020. The copyright holder for this preprint (which was not certified by peer review) is the author/funder, who has granted medRxiv a license to display the preprint in

It is made available under a CC-BY-NC-ND 4.0 International license .

\title{
Inflammasome activation in COVID-19 patients
}

Tamara S. Rodrigues ${ }^{1}$, Keyla S.G. de Sá1 ${ }^{\text {, Adriene Y. Ishimoto }}{ }^{1}$, Amanda Becerra ${ }^{1}$, Samuel Oliveira ${ }^{1}$, Leticia Almeida ${ }^{1,2}$, Augusto V. Gonçalves ${ }^{1}$, Debora B. Perucello ${ }^{1}$, Warrison A. Andrade ${ }^{1}$, Ricardo Castro ${ }^{3}$ Flavio P. Veras ${ }^{4}$, Juliana E. Toller-

Kawahisa ${ }^{4}$, Daniele C. Nascimento ${ }^{4}$, Mikhael H.F. de Lima ${ }^{4}$, Camila M. S. Silva ${ }^{4}$, Diego B. Caetite ${ }^{4}$, Ronaldo B. Martins ${ }^{1}$, Italo A. Castro ${ }^{1}$, Marjorie C. Pontelli ${ }^{1}$, Fabio C. de Barros $^{5,6}$, Natália B. do Amaral ${ }^{7}$, Marcela C. Giannini ${ }^{7}$, Letícia P. Bonjorno ${ }^{7}$, Maria Isabel F. Lopes ${ }^{7}$, Maíra N. Benatti ${ }^{7}$, Rodrigo C. Santana ${ }^{7}$, Fernando C. Vilar ${ }^{7}$, Maria Auxiliadora-Martins ${ }^{8}$, Rodrigo Luppino-Assad ${ }^{7}$, Sergio C.L. de Almeida ${ }^{7}$, Fabiola R. de Oliveira ${ }^{7}$, Sabrina S. Batah ${ }^{9}$, Li Siyuan ${ }^{9}$, Maira N. Benatti ${ }^{9}$, Thiago M. Cunha $^{2,4}$, José C. Alves-Filho ${ }^{2,4}$, Fernando Q. Cunha ${ }^{2,4}$, Larissa D. Cunha ${ }^{1}$, Fabiani G. Frantz $^{3}$, Tiana Kohlsdorf ${ }^{5}$, Alexandre T. Fabro ${ }^{9}$, Eurico Arruda ${ }^{1}$, Renê D.R. de Oliveira $^{7}$, Paulo Louzada-Junior ${ }^{7}$, Dario S. Zamboni ${ }^{1,2 *}$

${ }^{1}$ Departamento de Biologia Celular e Molecular e Bioagentes Patogênicos and ${ }^{2}$ Center of Research in Inflammatory Diseases (CRID), Faculdade de Medicina de Ribeirão Preto, Universidade de São Paulo, Ribeirão Preto, São Paulo, Brazil.

${ }^{3}$ Departamento de Análises Clínicas, Toxicológicas e Bromatologia, Faculdade de Ciências Farmacêuticas de Ribeirão Preto, Universidade de São Paulo, Ribeirão Preto, SP, Brazil.

${ }^{4}$ Departamento de Farmacologia, Faculdade de Medicina de Ribeirão Preto, Universidade de São Paulo, Ribeirão Preto, São Paulo, Brazil.

${ }^{5}$ Departamento de Biologia, Faculdade de Filosofia Ciências e Letras de Ribeirão Preto, Universidade de São Paulo, Ribeirão Preto, SP, Brazil.

${ }^{6}$ Departamento de Ecologia e Biologia Evolutiva, Instituto de Ciências Ambientais, Químicas e Farmacêuticas, Universidade Federal de São Paulo, Diadema, SP, Brazil. ${ }^{7}$ Divisão de Imunologia Clinica, Emergência, Doenças Infecciosas e Unidade de Terapia Intensiva, Faculdade de Medicina de Ribeirão Preto, Universidade de São Paulo, Ribeirão Preto, SP, Brazil.

${ }^{8}$ Divisão de Medicina Intensiva, Departamento de Cirurgia e Anatomia, Faculdade de Medicina de Ribeirão Preto, Universidade de São Paulo, Ribeirão Preto, SP, Brazil. ${ }^{9}$ Departamento de Patologia e Medicina Legal, Faculdade de Medicina de Ribeirão Preto, Universidade de São Paulo, Ribeirão Preto, SP, Brazil.

*Correspondence:

Dario S. Zamboni, Ph.D.

Departamento de Biologia Celular e Molecular e Bioagentes Patogênicos. Av.

Bandeirantes 3900, Ribeirão Preto, SP 14049-900 Brazil.

Tel: (55) (16) 3602-3265.

Fax: (55) (16) 3633-1786.

E-mail: dszamboni@,fmrp.usp.br 
medRxiv preprint doi: https://doi.org/10.1101/2020.08.05.20168872; this version posted August 6, 2020. The copyright holder for this preprint (which was not certified by peer review) is the author/funder, who has granted medRxiv a license to display the preprint in It is made available under a CC-BY-NC-ND 4.0 International license

47 Abstract

48

Severe cases of COVID-19 are characterized by a strong inflammatory

50 process that may ultimately lead to organ failure and patient death. The NLRP3

51 inflammasome is a molecular platform that promotes inflammation via cleavage and

52 activation of key inflammatory molecules including active caspase-1 (Casp1p20), IL-

$531 \beta$ and IL-18. Although the participation of the inflammasome in COVID-19 has been

54 highly speculated, the inflammasome activation and participation in the outcome of

55 the disease is unknown. Here we demonstrate that the NLRP3 inflammasome is

56 activated in response to SARS-CoV-2 infection and it is active in COVID-19,

57 influencing the clinical outcome of the disease. Studying moderate and severe

58 COVID-19 patients, we found active NLRP3 inflammasome in PBMCs and tissues of

59 post-mortem patients upon autopsy. Inflammasome-derived products such as

60 Casp1p20 and IL-18 in the sera correlated with the markers of COVID-19 severity,

61 including IL-6 and LDH. Moreover, higher levels of IL-18 and Casp1p20 are

62 associated with disease severity and poor clinical outcome. Our results suggest that

63 the inflammasome is key in the pathophysiology of the disease, indicating this

64 platform as a marker of disease severity and a potential therapeutic target for COVID-

6519.

66 
medRxiv preprint doi: https://doi.org/10.1101/2020.08.05.20168872; this version posted August 6, 2020. The copyright holder for this preprint (which was not certified by peer review) is the author/funder, who has granted medRxiv a license to display the preprint in It is made available under a CC-BY-NC-ND 4.0 International license .

COVID-19 is an inflammatory disease caused by the severe acute respiratory syndrome coronavirus 2 (SARS-CoV-2), which can manifest a broad spectrum of symptoms ranging from little or no symptoms to severe pneumonia that may evolve to acute respiratory distress syndrome (ARDS) and death ${ }^{1}$. While the molecular mechanisms driving disease severity are still unclear, the clinical association of inflammatory mediators such as IL-6 and lactate dehydrogenase (LDH) with severe cases suggests that excessive inflammation is central for the poor clinical outcome ${ }^{2-5}$.

The induction of inflammatory processes in the host cell often requires the engagement of the inflammasomes, which are protein platforms that aggregate in the cytosol in response to different stimuli ${ }^{6}$. The NLRP3 inflammasome, possibly the most studied one of such platforms, comprises the NLRP3 receptor, the adaptor molecule ASC, and caspase-1. Caspase-1 is activated by proteolytically cleavage and promotes the activation of many substrates, including the inflammatory cytokines IL-

$81 \quad 1 \beta$ and IL-18 and Gasdermin-D, a pore-forming protein that induces an inflammatory 82 form of cell death called pyroptosis ${ }^{6}$. NLRP3 activation in response to microbial infections, cell damage, or aggregates in the host cell cytoplasm promotes ASC polymerization, leading to the formation of a micron-sized structure called puncta (or speck) that is a hallmark of active inflammasomes in the cells ${ }^{7}$. correlation of disease severity with the pyroptosis marker LDH prompted us to 89 investigate the activation of the inflammasome by SARS-CoV-2 and its role in 90 disease development. Initially, we infected primary human monocytes in vitro with 91 SARS-CoV-2 and assessed inflammasome activation. Using monocytes from 
medRxiv preprint doi: https://doi.org/10.1101/2020.08.05.20168872; this version posted August 6, 2020. The copyright holder for this preprint (which was not certified by peer review) is the author/funder, who has granted medRxiv a license to display the preprint in It is made available under a CC-BY-NC-ND 4.0 International license .

different healthy donors, we found that SARS-CoV-2 infection triggers LDH release and activation of NLRP3 inflammasome in monocytes, as shown by NLRP3 puncta formation (Fig. 1A-C). As expected, uninfected cells were negative for dsRNA staining and NLRP3 puncta formation. Nigericin, a bacterial toxin known to trigger NLRP3 inflammasome, was used as a positive control. Activation of the NLRP3 inflammasome required viable virus particles, as UV-inactivated SARS-CoV-2 failed to induce NLRP3 puncta formation (Fig. 1B). We also measured the activation of IL$1 \beta$ as a readout for inflammasome activation and found that infection with SARSCoV-2 caused the production of IL-1 $\beta$ in primed cells, as measured by ELISA (Fig. 1D). We measured the viral load using RT-PCR and confirmed that SARS-CoV-2 infects and replicates in primary human monocytes in vitro (Fig. 1E). We also tested infection in primary human monocyte-derived macrophages and found that SARSCoV-2 infection triggers macrophage cell death in a dose-dependent effect as shown by the presence of LDH in the supernatants (Fig. 1F). Nigericin was used as positive control and UV-inactivated virus as a negative control. We next tested the inflammasome activation in the sera of COVID-19 patients. It was previously shown that IL-1 $\beta$ is activated independently of caspase- 1 in vivo ${ }^{8-10}$, thus we assessed active/cleaved caspase-1 (Casp1p20) and cleaved IL-18 as readouts for inflammasome activation in COVID-19 patients. We tested sera from 124 COVID-19 patients obtained on the day of hospitalization (all tested RT-PCR positive for SARS$\mathrm{CoV}-2$ ) and compared with sera of 42 controls that tested RT-PCR/serology negative or that were collected before the COVID-19 pandemic. We found higher concentrations of Casp1p20 and IL-18 in the sera of patients (Fig. 2A, B), suggesting active inflammasome in COVID-19 patients. We also found that IL-6, IL-10, IL-4 were increased in patients as compared to controls, whereas we do not detect 
117 statistically significant differences for IL-2, TNF- $\alpha$, and IL-17A (Fig. 2C and Fig.

118 S1). IFN- $\gamma$ levels were slightly lower in COVID-19 patients as compared to controls

119 (Fig. S1). Next, we measured inflammasome activation in peripheral blood

120 mononuclear monocytes (PBMCs) from 47 patients and compared them with 32

121 healthy individuals. Using the FAM-YVAD assay that stains active intracellular

122 caspase- $1^{11}$, we found that, on the day of hospitalization, the PBMCs from patients

123 show a higher percentage of FAM-YVAD+ cells as compared to healthy controls

124 (Fig. 2D-E). Microscopy observation of these cells allows clear visualization of

125 NLRP3 puncta in PBMCs, indicating active inflammasomes in patients cells (Fig. 2F-

126 G). We further confirmed caspase-1 activation using a luminescent assay and found

127 active caspase-1 in supernatants from 46 patients PBMCs cultures, as opposed to low

128 caspase-1 activation in healthy donors (Fig. $2 \mathbf{H})$. We also detected IL-1 $\beta$ in the

129 supernatants of PBMCs from some patients, but not from healthy donors (Fig. 2I),

130 further supporting inflammasome activation in PBMCs from COVID-19 patients.

We further assessed inflammasome activation in lung tissues obtained from autopsies of deceased COVID-19 patients. Using an anti-SARS-CoV-2 antibody, we

134 first confirmed viral presence by immunohistochemical staining SARS-CoV-2 in

135 injured regions of post-mortem lung tissues (Fig. 3A,B). We then performed

136 Multiplex Staining by Sequential Immunohistochemistry with SARS-CoV-2, anti-

137 CD14, and anti-NLRP3 and identified infected CD14+ cells expressing NLRP3 in

138 post-mortem tissues (Fig. 3C, D). Using multiphoton microscopy, we quantified the

139 number of NLRP3 puncta in tissues 5 controls and 6 COVID-19 patients and found

140 that patients contain higher numbers of NLRP3 puncta as compared to controls. (Fig.

141 3E). Images of tissues stained with anti-NLRP3 antibody illustrates NLRP3 puncta in 
142 of lethal cases of COVID-19 (Fig. 3F-I). We observed NLRP3 puncta inside cells in

143 the tissues and also cells contained in venules (Fig. 3I), unequivocally demonstrating

144 activation of the NLRP3 inflammasome in fatal cases of COVID-19.

We next assessed the impact of the inflammasome activation in the clinical outcome of the disease. Initially, we performed analyses using the levels of Casp1p20 and IL-18 in 124 patients sera obtained on the day of hospitalization. A correlation matrix show association of Casp1p20 and IL-18 levels with patient characteristics and

150 clinical parameters (Fig. 4A). As expected, we found a positive correlation between

151 Casp1p20 and IL-18 levels (Fig. 4B). In addition, Casp1p20 positively correlated with IL-6, LDH and C-reactive protein (CRP) (Fig. 4C-E). Furthermore, we found evaluated if the levels of Casp1p20 and IL-18 were affected by patients comorbidities and clinical parameters, including bacterial co-infections (cultivable bacteria in the

156 blood), nephropathy, obesity, gender, cerebrovascular accident, pneumopathy, immunodeficiency and neoplasia (Fig. S2). We only detected statistically significant differences when we compared obese with non-obese patients, as the levels of IL-18 were higher in patients with body mass index $\geq 30$ (Fig. S2G).

162 hospitalization correlated with the clinical outcome of the disease. Importantly, we

163 found that IL-18, but not Casp1p20 were higher in patients who required mechanical

164 ventilation (MV) as compared with patients that did not (Fig. 4H, I). When we

165 separated the patients according to the severity of the disease (mild/moderate versus severe), we found that the levels of Casp1p20 but not IL-18 were higher in patients 
167 with the severe form of COVID-19 (Fig. 4J, K). We also observed that the levels of

168 IL-18, but not Casp1p20, were higher in lethal cases of COVID-19 as compared to

169 survivors (Fig. 4L, M). Finally, we performed longitudinal analyses of IL-18 and

170 Casp1p20 production in 37 patients from the day of hospitalization (day zero) for up

171 to 45 days post-admission using generalized mixed models with 'gamma' distribution

172 and 'log' link function as the best dataset prediction. For these analyses, we

173 categorized the patients as Death, Mild-Recovery (patients that were hospitalized but

174 did not require mechanical ventilation and recovered), and Critical-Recovery (patients

175 that required mechanical ventilation at the Intensive Care Unit (ICU) and recovered)

176 (Supplemental data). For Casp1p20, the most parsimonious model indicated a

177 significant effect of the day sampled, and the production level decreased with time

178 regardless of sex or patient outcome (Fig. 4N, and Supplemental data). For IL-18,

179 the best-fit model retained also described an overall reduction in IL-18 production

180 along time (Day sampled), which differed among patient groups. This model

181 predicted a decrease in IL-18 at similar rates among the three groups, with patients

182 that died presenting higher levels (intercept) that never reached those observed in

183 mild and critical recovered patients (Fig. 40 and Supplemental data), supporting our

184 assertion that the magnitude of inflammasome activation impacts the disease

185 outcome. In summary, our data demonstrate that the inflammasome is robustly active

186 in COVID-19 patients requiring hospitalization. It also supports that both the

187 magnitude of inflammasome activation at the hospitalization day and the course of

188 inflammasome activation during hospitalization influenced the clinical outcome.

189 Collectively, our observations suggest that the inflammasome is key for the induction

190 of the massive inflammation observed in severe and fatal cases of COVID-19. Our 
medRxiv preprint doi: https://doi.org/10.1101/2020.08.05.20168872; this version posted August 6, 2020. The copyright holder for this preprint (which was not certified by peer review) is the author/funder, who has granted medRxiv a license to display the preprint in It is made available under a CC-BY-NC-ND 4.0 International license .

191 study supports the use of inflammasome activation both as a marker of disease

192 severity and prognostic but also as a potential therapeutic target for COVID-19.

195 Materials and methods

196

197 Patients

198 A total of 124 patients with COVID-19 that were tested positive using RT-PCR as

199 described previously ${ }^{12,13}$. Patients were classified according to their clinical

200 manifestations in: i) mild cases: the clinical symptoms are mild and no pneumonia

201 manifestations can be found in imaging; ii) moderate cases: patients have symptoms

202 such as fever and respiratory tract symptoms, etc. and pneumonia manifestations can

203 be seen in imaging; iii) severe cases: adults who meet any of the following criteria:

204 respiratory rate $\geq 30$ breaths/min; oxygen saturations; $93 \%$ at a rest state; arterial

205 partial pressure of oxygen $\left(\mathrm{PaO}_{2}\right)$ /oxygen concentration $\left(\mathrm{FiO}_{2}\right)<300 \mathrm{~mm} \mathrm{Hg}{ }^{14}$.

206 Patients were enrolled in HC-FMRP/USP from April 06 to July 02, 2020 and Table

207 S1 summarizes clinical, laboratory, and treatment records. We also collected samples

208 from 73 age and gender-matched healthy controls. Controls were collected either

209 before the COVID-19 pandemic or tested negative for COVID-19 using RT-PCR

210 and/or serology (specific IgM and IgG antibodies) (Asan Easy Test.COVID-19

211 IgM/IgG kits, Asan Pharmaceutical Co.).

212

\section{Peripheral blood mononuclear cells isolation}

214 Whole blood was collected from healthy donors (Ethics Committee Protocol from the

215 Clinical Hospital of Ribeirão Preto- USP: CAAE, $n^{\circ}$ 06825018.2.3001.5440) in tubes 
medRxiv preprint doi: https://doi.org/10.1101/2020.08.05.20168872; this version posted August 6, 2020. The copyright holder for this preprint (which was not certified by peer review) is the author/funder, who has granted medRxiv a license to display the preprint in It is made available under a CC-BY-NC-ND 4.0 International license .

containing EDTA (BD Vacutainer CPTTM), according to the manufacturer's

217 instructions. The material was centrifuged at $400 \mathrm{x}$ g for 10 minutes at room

218 temperature. Then, the plasma was discarded and the cell pellet was resuspended in

219 PBS $1 \mathrm{X}$ pH 7.4 (GIBCO, BRL). The cells were applied to the Ficoll-PaqueTM PLUS

gradient column (GE Healthcare Biosciences AB, Uppsala, Sweden). Then, they were centrifuged at $640 \mathrm{x}$ g for 30 minutes at room temperature to obtain the purified mononuclear fraction, which was carefully collected and transferred to a new tube. The cells were washed and the pellet was resuspended in RPMI for the subsequent 224 analysis.

\section{Purification of monocytes from healthy donors and differentiation into}

macrophages

The PBMCs were quantified and the monocytes (CD14+ cells) were purified using positive selection with magnetic nanoparticles (BD). Briefly, PBMCs were labeled

230 with BD IMagTM Anti-human CD14 Magnetic Particles - DM. The cells were 231 transferred to a 48-well culture plate and placed over a magnetic field of the cell

232 separation. Labeled cells migrated toward the magnet (positive fraction) whereas

233 unlabeled cells were drawn off (negative fraction). The plate was then removed from

234 the magnetic field for resuspension of the positive fraction. The separation was

235 repeated twice to increase the purity of the positive fraction. The CD14 + monocytes 236 resulting cells from this process were used for experiments or cultured in RPMI 1640

237 (GIBCO, BRL) containing 10\% SFB and $50 \mathrm{ng} / \mathrm{mL}$ GM-CSF (R\&D Systems) for 7 238 days for differentiation into macrophages. 
medRxiv preprint doi: https://doi.org/10.1101/2020.08.05.20168872; this version posted August 6, 2020. The copyright holder for this preprint (which was not certified by peer review) is the author/funder, who has granted medRxiv a license to display the preprint in It is made available under a CC-BY-NC-ND 4.0 International license .

241 The SARS-CoV-2 used was Brazil/SPBR-02/2020 strain, isolated from the first

242 Brazilian case of COVID-19. Viral stock was propagated under BSL3 conditions in

243 Vero E6 cells, cultured in Dulbecco minimal essential medium (DMEM)

244 supplemented with heat-inactivated fetal bovine serum (10\%) and

245 antibiotics/antimycotics (Penicillin 10,000 U/mL; Streptomycin 10,000 $\mu \mathrm{g} / \mathrm{mL}$ ). For

246 preparation of viral stocks, Vero cells were infected in the presence of trypsin-TPCK

$247(1 \mu \mathrm{g} / \mu \mathrm{L})$ for 48 hours at $37^{\circ} \mathrm{C}$ in a $5 \% \mathrm{CO}_{2}$ atmosphere. When the virus-induced

248 cytopathic effect, the cells were harvested with cell scrapers, and centrifuged (10.000

$249 \times \mathrm{x})$. The supernatant was stored at $-80^{\circ} \mathrm{C}$, and the virus titration was performed in

250 Vero cells using standard limiting dilution to confirm the $50 \%$ tissue culture

251 infectious dose (TCID50).

252 For human cells infections, $2 \times 10^{5}$ purified human monocytes or monocyte derived

253 macrophages were plated in 48 well plates, and infected with SARS-CoV-2 at

254 Multiplicity of Infection (MOI) of MOI0.2, MOI1, and MOI5. After 2 hours of viral

255 infection, the cells were washed with PBS1x, and a new medium (RPMI 10\% FBS

256 without Fenol Red) was added. Cells were incubated for $24 \mathrm{~h}$ at $37^{\circ} \mathrm{C}$ in the presence

257 of $5 \% \mathrm{CO}_{2}$ atmosphere. After incubation, cells were processed for

258 immunofluorescence assays and the supernatant was collected for determination of

259 viral loads, cytokine production and LDH quantification.

RT-PCR for SARS-CoV-2

262 Detection of SARS-CoV-2 was performed with primer-probe sets for 2019-nCoV_N2

263 and gene E, according to USA-CDC and Charité group protocols ${ }^{12,13}$. The genes

264 evaluated (N2, E, and RNAse-P housekeeping gene) were tested by one-step real-time

265 RT-PCR using total nucleic acids extracted with Trizol ${ }^{\circledR}$ (Invitrogen, CA, EUA) from 
medRxiv preprint doi: https://doi.org/10.1101/2020.08.05.20168872; this version posted August 6, 2020. The copyright holder for this preprint (which was not certified by peer review) is the author/funder, who has granted medRxiv a license to display the preprint in It is made available under a CC-BY-NC-ND 4.0 International license .

$26650 \mu \mathrm{L}$ of cells supernatants in order to measure the genome viral load from the in vitro 267 assays. All real-time PCR assays were done on Step-One Plus real-time PCR 268 thermocycler (Applied Biosystems, Foster City, CA, USA). Briefly, RNA extraction 269 was performed by Trizol®. A total of $100 \mathrm{ng}$ of RNA was used for genome 270 amplification, adding specifics primers $(20 \mu \mathrm{M})$, and probe $(5 \mu \mathrm{M})$, and with TaqPath 271 1-Step qRT-PCR Master Mix (Applied Biosystems, Foster City, CA, USA), with the 272 following parameters: $25^{\circ} \mathrm{C}$ for $2 \mathrm{~min}, 50^{\circ} \mathrm{C}$ for $15 \mathrm{~min}, 95^{\circ} \mathrm{C}$ for $2 \mathrm{~min}$, followed by 27345 cycles of $94{ }^{\circ} \mathrm{C}$ for $5 \mathrm{~s}$ and $60{ }^{\circ} \mathrm{C}$ for 30 s. Primers used were: N2 fwd: $5^{\prime}$-TTA 274 CAA ACA TTG GCC GCA AA-3'; N2 rev: 5'-GCG CGA CAT TCC GAA GAA-3'; 275 N2 probe: 5'-FAM-ACA ATT TGC CCC CAG CGC TTC AG-BHQ1-3'13; E fwd: 5'-ACA GGT ACG TTA ATA GTT AAT AGC GT-3' ; E rev: 5'-ATA TTG CAG

CAG TAC GCA CAC A-3' ; E probe: 5'-AM-ACA CTA GCC ATC CTT ACT GCG CTT CG-BHQ-1-3' '12; RNAse-P fwd: 5'-AGA TTT GGA CCT GCG AGC G-3'; 279 RNAse-P rev: 5'-GAG CGG CTG TCT CCA CAA GT-3'; RNAse-P probe: 5'-FAM280 TTC TGA CCT GAA GGC TCT GCG CG - BHQ-1-3’ ${ }^{13}$.

\section{Evaluation of active caspase-1 activity and LDH release in cultured cells}

For LDH determination, 2 x $10^{5}$ human CD14+ cells or human monocyte derived-

284 macrophages were plated on 48-well plates in RPMI 10\% FBS and incubated 285 overnight. In the following day, cells were infected with SARS-CoV-2 using MOI 0.2, MOI 1, and MOI 5 in RPMI without Phenol Red (3.5 g/L HEPES, 2 g/L

$287 \mathrm{NaHCO}_{3}, 10.4 \mathrm{~g} / \mathrm{L}$ RPMI without Phenol Red, 1\% glutamine, pH 7.2) and incubated 288 for $24 \mathrm{~h}$. The supernatant was collected and LDH release was measured using 289 CytoTox 96® Non-Radioactive Cytotoxicity Assay (Promega, Winsconsin, USA) 290 following the manufacturer's instructions. To evaluate caspase- 1 activation, $5 \times 10^{5}$ 
medRxiv preprint doi: https://doi.org/10.1101/2020.08.05.20168872; this version posted August 6, 2020. The copyright holder for this preprint (which was not certified by peer review) is the author/funder, who has granted medRxiv a license to display the preprint in It is made available under a CC-BY-NC-ND 4.0 International license .

291 PBMC from COVID-19 patients or healthy donors were centrifuged (400g, 10

292 minutes) and cells were labeled for 30 minutes with the FLICA carboxyfluorescein

293 reagent (FAM - YVAD - FMK, Immunochemistry Technologies, LLC), as

294 recommended by the manufacturer. The cells were then washed two times with PBS

$2951 x$, and fixed with fixative reagent provided by manufacture. Acquisition was

296 performed in fixed cells in flow cytometer (BD Accuri ${ }^{\mathrm{TM}}$ C6) and then analyzed using

297 "FlowJo" (Tree Star, Ashland, OR, USA) software. To evaluate caspase-1 activity in

298 supernatants, $2 \times 10^{5}$ PBMCs were plated in 96 wells plate, and incubated overnight.

299 To measure caspase-1 activity, the supernatants were collected, and incubated with

300 the Luciferin WEHD-substrate provided by the Caspase-Glo 1 Assay (Promega).

301 After 1 hour incubation at room temperature, luminescence was measured using

302 SpectraMax i3 system (Molecular Devices).

303

304 Immunofluorescence staining of isolated cells

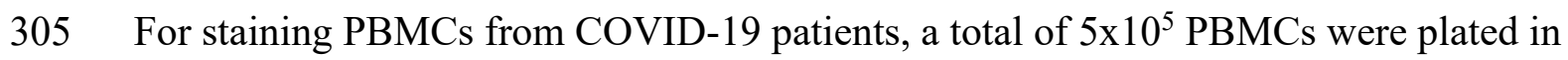

3068 wells chamber slides for $1 \mathrm{~h}$ in RPMI without FBS for cell adhesion before fixation.

307 For staining cells infected in vitro a total of $2 \times 10^{5}$ human monocytes or monocyte

308 differentiated macrophages were plated in 24-wells plate containing coverslips and

309 infected with SARS-CoV-2 at indicated MOI for $16 \mathrm{~h}$. For fixation of the samples,

310 tissue culture supernatants were removed and cells were fixed with $4 \%$

311 paraformaldehyde (PFA) for 20 minutes at room temperature. PFA was removed,

312 cells were washed with PBS1x, and the coverslips or chambers were processed for IF

313 as described. Cells were blocked and permeabilized using PBS 1x with goat serum

314 and $0.05 \%$ saponin for $1 \mathrm{~h}$ at room temperature. Primary antibodies mix of rabbit mAb

315 anti-NLRP3 (Cell Signaling, 1:1000) were diluted in blocking solution and added to 
medRxiv preprint doi: https://doi.org/10.1101/2020.08.05.20168872; this version posted August 6, 2020. The copyright holder for this preprint (which was not certified by peer review) is the author/funder, who has granted medRxiv a license to display the preprint in It is made available under a CC-BY-NC-ND 4.0 International license .

316 each chamber/coverslip. After $1 \mathrm{~h}$ of incubation the samples were washed with PBS 1x

317 and secondary antibodies were added and incubated for $1 \mathrm{~h}$ at room temperature.

318 Secondary antibodies used were goat anti-rabbit 488 (Invitrogen,1:3000) and goat

319 anti-rabbit 594 (Life Technologies, 1:3000). Slides were washed and mounted using

320 DAPI (1mM) and ProLong (Invitrogen).

321

322 Lung samples from autopsies and immunofluorescence and imaging

323 Adapted minimally invasive autopsies were performed in COVID-19 patients ${ }^{15-17}$.

324 Briefly, a mini thoracotomy $(3 \mathrm{~cm})$ was done under the main area of lung injury

325 identified by prior x-ray or computed tomography. The lung parenchyma is clamped

326 by Collins Forceps, cut and fixed in $10 \%$ buffered formalin. Pulmonary tissue

327 samples were stained with hematoxylin and eosin (H\&E) and immunostaining as

328 reported ${ }^{18}{ }^{19}$. The slides were incubated with the primary antibodies, rabbit anti-

$329 \mathrm{CD} 14 \mathrm{mAb}($ Abcam, 1:200) and mouse anti-Nlrp3 mAb (AdipoGen, 1:200), for 2h at

330 room temperature or overnight at $4^{\circ} \mathrm{C}$. Goat anti-mouse Alexa fluor-647 (Invitrogen)

331 or goat anti-rabbit Alexa fluor-594 (Invitrogen) were used as secondary antibodies.

332 Images were acquired by Axio Observer combined with LSM 780 confocal device

333 with 630 x magnification (Carl Zeiss). Minimally invasive autopsies were approved

334 by the FMRP/USP Ethical Committee (protocol \#4.089.567).

336 Sequential immunoperoxidase labeling and erasing

337 Tissue sections from paraffin-embedded lung fragments obtained from COVID-19

338 fatal cases were tested by immunohistochemistry (IHC) using anti-SARS-CoV-2

339 polyclonal antibody for in situ detection of SARS-CoV-2. Sequential

340 immunoperoxidase labeling and erasing (SIMPLE) was then performed to determine 
medRxiv preprint doi: https://doi.org/10.1101/2020.08.05.20168872; this version posted August 6, 2020. The copyright holder for this preprint (which was not certified by peer review) is the author/funder, who has granted medRxiv a license to display the preprint in It is made available under a CC-BY-NC-ND 4.0 International license .

341 additional markers after SARS-CoV-2 immune stain, using antibodies to CD14

342 (Abcam, 1:100 dilution), NLRP3 (Cell Signaling, 1:100 dilution) (Glass et al., 2009).

343 After the incubation with primary antibody, the slides were incubated with immune-

344 peroxidase polymer anti-mouse visualization system (SPD-125, Spring Bioscience,

345 Biogen) and then with the chromogen substrate AEC peroxidase system kit (SK-4200,

346 Vector Laboratories, Burlingame, CA). Microphotographs after immunostaining of

347 tissue slides were scanned on a VS120 Olympus. After high-resolution scanning,

348 slides coverslips were removed in PBS and dehydrated through ethanol gradient to

$34995 \%$ ethanol. Slides were incubated in ethanol series until erasing AEC color reaction.

350 Following rehydration, antibodies were eluted by incubating sections in $0.15 \mathrm{mM}$

$351 \mathrm{KMnO}_{4} / 0.01 \mathrm{M} \mathrm{H}_{2} \mathrm{SO}_{4}$ solution for $2 \mathrm{~min}$, followed immediately by a distilled water

352 wash. Tissue was then restained as indicated in the blocking step.

354 Cytokine quantification in sera

355 Active caspase-1 (Casp1p20) and IL-18 levels were evaluated by ELISA assay (R\&D

356 Systems) in the serum from patients with COVID-19 or health donors following

357 manufacturer's instructions. TNF- $\alpha$, IL-2, IL-4, IL-6, IL-10, IFN- $\gamma$, and IL-17 were

358 quantified in the serum from patients with COVID-19 or health donors using a human

359 CBA cytokine kit (Th1/Th2/Th17 Cytokine Kit, BD Biosciences) following

360 manufacturer's instructions. IL-1 $\beta$ in the tissue culture supernatants of human

361 monocytes or macrophages cells infected with SARS-CoV-2 was quantified by

362 ELISA (R\&D Systems) following manufacturer's instructions.

\section{Statistics}


365 Statistical significance for the linear analysis was determined by either two-tailed

366 paired or unpaired Student t-test for data that reached normal distribution and Mann-

367 Whitney was used for not normally distributed data. These statistical procedures and

368 graph plots were performed with GraphPad Prism 8.4.2 software. In addition,

369 longitudinal analyses were implemented to describe variation in IL-18 and Casp1p20

370 production along time, considering patients' outcomes and sex as fixed factors. These

371 analyses were performed in R (version 4.0.2) using RStudio (version 1.3.1056), and

372 are detailed as R Markdown object at the supplementary material. The patients'

373 outcomes were divided into 3 categories (37 patients in total, 16 women and 21 men):

374 death $(\mathrm{n}=10$ individuals, a total of 25 samples), mild recovery (patients that were

375 hospitalized but did not require mechanical ventilation; $n=17$ individuals, a total of

37653 samples) and critical recovery (patients that required mechanical ventilation at the

377 UCI and recovered; $\mathrm{n}=10$ individuals, a total of 27 samples). Activation of IL-18 and

378 Casp1 were evaluated separately using full models that considered the interaction of

379 time ('Day.sampled') with patients' outcomes ('Outcome') or sex ('Sex') and

380 included individuals ('Patient.ID') as a random factor to control for repeated

381 measures and individual effects. Normality and homoscedasticity of the dataset were

382 verified and refuted for time series dataset (see RMarkdown object), and analyses

383 were implemented using the glmmTMB package ${ }^{20}$ in a generalized mixed model's

384 (GMM's) approach with 'gamma' distribution and 'log' link function. Akaike

385 information criterion for finite samples (AICc) was used to select the best models

386 from the full ones using MuMIn ${ }^{21}$. Models having AICc values within 2 units of the

387 best-fit model were considered to have substantial support ${ }^{22}$; adequate residuals

388 distributions were confirmed and representative graphics and tables were constructed 
medRxiv preprint doi: https://doi.org/10.1101/2020.08.05.20168872; this version posted August 6, 2020. The copyright holder for this preprint (which was not certified by peer review) is the author/funder, who has granted medRxiv a license to display the preprint in It is made available under a CC-BY-NC-ND 4.0 International license .

389

390

391

\section{Study approval}

393 The procedures followed in the study were approved by the National Ethics

394 Committee, Brazil (CONEP, CAAE: 30248420.9.0000.5440). Written informed

395 consent was obtained from recruited patients. Khouri for technical assistance.

400

401 analyses of the data. N.B.A., M.C.G., L.P.B., M.I.F.L., M.N.B., R.C.S., F.C.V., M.A., R.L., S.C.L.A., F.R.O., R.D.R.O., P.L assisted in patient recruitment, collected patient

412 specimens and the epidemiological and clinical data. P.L. supervised and R.D.R.O.

413 helped clinical data management. T. M.C, J.C.A., F.Q.C., L.D.C., F.G.F., T.K., 
medRxiv preprint doi: https://doi.org/10.1101/2020.08.05.20168872; this version posted August 6, 2020. The copyright holder for this preprint (which was not certified by peer review) is the author/funder, who has granted medRxiv a license to display the preprint in It is made available under a CC-BY-NC-ND 4.0 International license .

414 A.T.F., E.A., R.D.R.O., P.L., helped with interpretations of the data. T.S.R., and

415 D.S.Z. drafted the manuscript. All authors helped editing the manuscript. D.S.Z.

416 secured funds and supervised the project.

417

418

419 Competing interests

420 The authors declare no competing financial interests.

421

422 Materials \& Correspondence

423 dszamboni@ffmrp.usp.br

424

425

Funding

426

FAPESP grants (2013/08216-2, 2019/11342-6 and 2020/04964-8), CNPq and CAPES

427 grants.

428

429

430

References

431

432

1 Merad, M. \& Martin, J. C. Author Correction: Pathological inflammation in

433

434

435 patients with COVID-19: a key role for monocytes and macrophages. Nature

436 reviews. Immunology 20, 448, doi:10.1038/s41577-020-0353-y (2020).

2 Chen, G. et al. Clinical and immunological features of severe and moderate coronavirus disease 2019. The Journal of clinical investigation 130, 2620-

437

438 2629, doi:10.1172/JCI137244 (2020).

439

3 Han, Y. et al. Lactate dehydrogenase, an independent risk factor of severe

440

441

442

443

444

445

446 COVID-19 patients: a retrospective and observational study. Aging 12, 11245-

1258, doi:10.18632/aging.103372 (2020)

$4 \quad$ Huang, C. et al. Clinical features of patients infected with 2019 novel coronavirus in Wuhan, China. Lancet 395, 497-506, doi:10.1016/S01406736(20)30183-5 (2020).

5 Lucas, C. et al. Longitudinal analyses reveal immunological misfiring in severe COVID-19. Nature, doi:https://doi.org/10.1038/s41586-020-2588-y (2020). 
4476 Broz, P. \& Dixit, V. M. Inflammasomes: mechanism of assembly, regulation

448

449

450

451

452

453

454

455

456

457

458

459

460

461

462

463

464

465

466

467

468

469

470

471

472

473

474

475

476

477

478

479

480

481

482

483

484

485

486

487

488

489

490

491

492

493

494

495 and signalling. Nature reviews. Immunology 16, 407-420, doi:10.1038/nri.2016.58 (2016).

7 Hauenstein, A. V., Zhang, L. \& Wu, H. The hierarchical structural architecture of inflammasomes, supramolecular inflammatory machines. Current opinion in structural biology 31, 75-83, doi:10.1016/j.sbi.2015.03.014 (2015).

8 Alfaidi, M. et al. Neutrophil elastase promotes interleukin-1beta secretion from human coronary endothelium. The Journal of biological chemistry 290 , 24067-24078, doi:10.1074/jbc.M115.659029 (2015).

9 Guma, M. et al. Caspase 1-independent activation of interleukin-1beta in neutrophil-predominant inflammation. Arthritis and rheumatism 60, 36423650, doi:10.1002/art.24959 (2009).

10 Joosten, L. A. et al. Inflammatory arthritis in caspase 1 gene-deficient mice: contribution of proteinase 3 to caspase 1-independent production of bioactive interleukin-1beta. Arthritis and rheumatism 60, 3651-3662, doi:10.1002/art.25006 (2009).

11 Zamboni, D. S. et al. The Birc1e cytosolic pattern-recognition receptor contributes to the detection and control of Legionella pneumophila infection. Nature immunology 7, 318-325, doi:10.1038/ni1305 (2006).

12 Corman, V. M. et al. Detection of 2019 novel coronavirus (2019-nCoV) by real-time RT-PCR. Euro surveillance : bulletin Europeen sur les maladies transmissibles $=$ European communicable disease bulletin $\mathbf{2 5}$, doi:10.2807/1560-7917.ES.2020.25.3.2000045 (2020).

13 Nalla, A. K. et al. Comparative Performance of SARS-CoV-2 Detection Assays Using Seven Different Primer-Probe Sets and One Assay Kit. Journal of clinical microbiology 58, doi:10.1128/JCM.00557-20 (2020).

14 Wu, Z. \& McGoogan, J. M. Characteristics of and Important Lessons From the Coronavirus Disease 2019 (COVID-19) Outbreak in China: Summary of a Report of 72314 Cases From the Chinese Center for Disease Control and Prevention. Jama, doi:10.1001/jama.2020.2648 (2020).

15 Avrahami, R., Watemberg, S., Hiss, Y. \& Deutsch, A. A. Laparoscopic vs conventional autopsy. A promising perspective. Archives of surgery 130, 407409, doi:10.1001/archsurg.1995.01430040069014 (1995).

16 Damore, L. J., 2nd, Barth, R. F., Morrison, C. D., Frankel, W. L. \& Melvin, W. S. Laparoscopic postmortem examination: a minimally invasive approach to the autopsy. Annals of diagnostic pathology 4, 95-98, doi:10.1016/s10929134(00)90018-2 (2000).

17 Vejrosta, Z. \& Bilder, J. [Pathogenesis of excessive mobility of the temporomandibular joint]. Ceskoslovenska stomatologie 75, 119-124 (1975).

18 Fabro, A. T. et al. The Th17 pathway in the peripheral lung microenvironment interacts with expression of collagen $\mathrm{V}$ in the late state of experimental pulmonary fibrosis. Immunobiology 220, 124-135, doi:10.1016/j.imbio.2014.08.011 (2015).

19 Fabro, A. T. et al. Yellow Fever-induced Acute Lung Injury. American journal of respiratory and critical care medicine 200, 250-252, doi:10.1164/rccm.201711-2267IM (2019).

20 Brooks, M. E. et al. glmmTMB Balances Speed and Flexibility Among Packages for Zero-inflated Generalized Linear Mixed Modeling. The $R$ Journal 9, 378-400 (2017). 
medRxiv preprint doi: https://doi.org/10.1101/2020.08.05.20168872; this version posted August 6, 2020. The copyright holder for this preprint (which was not certified by peer review) is the author/funder, who has granted medRxiv a license to display the preprint in It is made available under a CC-BY-NC-ND 4.0 International license .

$49621 \quad$ Barton, K. MuMIn: Multi-Model Inference. R package version 1.43.17.

497 https://CRAN.R-project.org/package=MuMIn ( 2020).

49822 Burnham, K. P. \& Anderson, D. R. Model Selection and Multimodel

499 Inference: a practical information-theoretic approach (2002).

50023 Hartig, F. DHARMa: Residual Diagnostics for Hierarchical (Multi-Level /

$501 \quad$ Mixed) Regression Models. R package version 0.3.2.0. https://CRAN.R-

$502 \quad$ project.org/package=DHARMa (2020).

50324 Lüdecke, D. ggeffects: Tidy Data Frames of Marginal Effects from Regression

$504 \quad$ Models. Journal of Open Source Software 3, 772, doi:10.21105/joss.00772

$505 \quad$ (2018).

50625 Bolker, B. \& Robinson, D. broom.mixed: Tidying Methods for Mixed Models.

507 R package version 0.2.6. https://CRAN.R-project.org/package=broom.mixed

508 (2020). 
medRxiv preprint doi: https://doi.org/10.1101/2020.08.05.20168872; this version posted August 6, 2020. The copyright holder for this preprint (which was not certified by peer review) is the author/funder, who has granted medRxiv a license to display the preprint in It is made available under a CC-BY-NC-ND 4.0 International license .

\section{Figure Legends}

515 Figure 1. Infection of primary human monocytes with SARS-CoV-2 triggers

516 inflammasome activation. (A-E) Human CD14+ monocytes were primed or not with

517 PAM3Cys (300ng/mL) for 4 hours and infected with SARS-CoV-2 at a multiplicity

518 of infection (MOI) of $0.2,1$ an 5 for $24 \mathrm{~h}$. Mock was used as a negative infection

519 control, and nigericin as a positive NLRP3 activation control. (A) LDH release was

520 measured in the supernatants from 5 different donors. Triton (9\%) was used to induce

521 cell death and estimate $100 \%$ death. (B) the percentage of cell containing NLRP3

522 puncta was estimated in cells from 5 different donors. (C) A representative image of a

523 monocyte containing NLRP3 puncta (green, indicated by arrows) and replicating

524 SARS-CoV-2, depicted by anti-dsRNA antibody staining (red, indicated by an

525 arrowhead) is shown. Nuclei stained in blue. Scale bar $5 \mu \mathrm{m}$. (D) IL-1 $\beta$ production

526 was analyzed in the tissue culture supernatants of monocytes infected or not infected

527 (MOCK) with the indicated MOI in experimental replicates. (D) Viral loads in the

528 cell culture supernatants were estimated by RT-PCR in monocytes infected for 8 and

$52924 \mathrm{hs}$ at the indicated MOI. (F) Monocytes from one donor were derived into

530 macrophage and primed with PAM3Cys $(300 \mathrm{ng} / \mathrm{mL})$ for 4 hours and infected with

531 SARS-CoV-2 at a MOI of 1, 5 and 10 and 20 for $24 \mathrm{~h}$. LDH were measured in the

532 supernatants of experimental replicates. Mock and UV-irradiated virus (U.V. Inat.)

533 was used as a negative infection control, and nigericin as a positive control. ${ }^{*} P<$

5340.05 , as determined by Student's t-test. Box shows the average \pm SD of the values. 
medRxiv preprint doi: https://doi.org/10.1101/2020.08.05.20168872; this version posted August 6, 2020. The copyright holder for this preprint (which was not certified by peer review) is the author/funder, who has granted medRxiv a license to display the preprint in It is made available under a CC-BY-NC-ND 4.0 International license .

Figure 2. Inflammasome activation in COVID-19 patients. (A-C) Cytokine and COVID-19 patients (COVID-19 P, n=124 to ELISA and 92 to CBA; all tested positive using RT-PCR). Active caspase-1 (Casp1p20, A) and IL-18 (B) were

540 measured by ELISA, and IL-6 (C) were measured by CBA. Data are shown as Log10541 transformed concentrations in pg/mL. (D-I) Peripheral Blood Mononuclear Cells

542 (PBMCs) were isolated from fresh blood of CT or COVID-19 P. (D-E) FAM-YVAD

543 positive PBMCs were estimated by FACS using FLICA Caspase-1 Assay Kit. (D)

544 Representative histograms or one representative CT and one COVID-19 P indicate the 545 gate for determination of the percentage of FAM-YVAD+ cells. (E) The percentage of FAM-YVAD+ cells for the $32 \mathrm{CT}$ and 47 COVID-19 P. (F) PBMCs from COVID$19 \mathrm{P}$ were stained with anti-dsRNA (red, indicating SARS-CoV-2 replication) and anti-NLRP3 (green) for determination of NLRP3 puncta (indicated by white arrows).

549 Dapi (blue) stains the nuclei. Scale bar $20 \mu \mathrm{m}$. (G) The percentage of cells with 550 NLRP3 puncta are shown for 24 CT and 17 COVID-19 P. (H) PBMCs from 18 CT and 46 COVID-19 $\mathrm{P}$ were maintained in culture for 16 hours and the supernatants

552 were assayed for caspase-1 activity using the Caspase-Glo 1 Assay (H). (I) PBMCs

553 from 6 CT or 18 COVID-19 P were maintained in culture for 16 hours and IL-1 $\beta$

554 production were estimated by ELISA. ${ }^{*} P<0.05,{ }^{* *} P<0.01$ and ${ }^{* * *} P<0.001$ as

555 determined by Student's t-test or Mann Whitney. Each dot represents the value form a 556 single individual. Box shows average \pm SD of the values. 
medRxiv preprint doi: https://doi.org/10.1101/2020.08.05.20168872; this version posted August 6, 2020. The copyright holder for this preprint (which was not certified by peer review) is the author/funder, who has granted medRxiv a license to display the preprint in

It is made available under a CC-BY-NC-ND 4.0 International license .

Figure 3. Lung histopathological analysis and NLRP3 activation in fatal cases of

COVID-19. Representative pulmonary histological findings in COVID-19 patient

560 (COVID-19 P), autopsied by ultrasound guided-minimally invasive autopsy. (A, B)

561 Representative Immunohistochemical image of tissues from Control (CT, A) or

562 COVID-19 P (B) stained with anti-SARS-CoV-2. Scale bar $50 \mu \mathrm{m}$. (C-D) Multiplex

563 staining by sequential immunohistochemistry staining with anti-SARS-CoV-2, anti-

564 CD14 and anti-NLRP3 arrows indicates infected CD14+ cells expressing NLRP3 .

565 Scale bar $20 \mu \mathrm{m}(\mathrm{C})$ and $10 \mu \mathrm{m}$ (D). (E) Quantification of NLRP3 puncta in

566 pulmonary tissues of 5 CT and 6 COVID-19 P. (F, I) Multiphoton microscopy of

567 tissues stained with anti-NLRP3 antibody indicates NLRP3 puncta (red, indicated by

568 black arrows) in the pulmonary tissues. DAPI stains nuclei (blue). (I) NLRP3 puncta

569 in a cell inside a venule (dotted white line). Scale bar $10 \mu \mathrm{m}$.

Figure 4. Inflammasome activation influences the clinical outcome of COVID-19.

573 (A) Correlation matrix of Casp1p20 and IL-18 levels in the serum of COVID-19

574 patients at the hospitalization day with patient characteristics and clinical parameters.

575 (B-J) Correlations of Casp1p20 with IL-18 (B), Casp1p20 with IL-6 (C), Casp1p20

576 with lactate dehydrogenase (LDH) (D), Casp1p20 with C-reactive protein (CRP), IL-

57718 with IL-6 (F) and IL-18 with CRP (G). (H,I) Levels of Casp1p20 (H) and IL-18 (I)

578 in patients that required $(\mathrm{MV}+$, blue box) or not $(\mathrm{MV}-$, red box $)$ mechanical

579 ventilation. $(\mathrm{J}, \mathrm{K})$ Levels of Casp1p20 (J) and IL-18 (K) in patients with

580 Mild/Moderate (yellow box) or Severe COVID-19 (pink box). (L,M) Levels of

581 Casp1p20 (L) and IL-18 (M) in survivors (green box) or non-survivors (purple box).

582 The levels of Casp1p20 and IL-18 were measured by ELISA and are shown as

583 Log10-transformed concentrations in pg/mL. $* P<0.05, * * P<0.01$ and $* * * P<$ 
medRxiv preprint doi: https://doi.org/10.1101/2020.08.05.20168872; this version posted August 6, 2020. The copyright holder for this preprint (which was not certified by peer review) is the author/funder, who has granted medRxiv a license to display the preprint in It is made available under a CC-BY-NC-ND 4.0 International license .

584

585

586

587

588

589

590

591

592

593

594

595

596

597

598

599

600

601

602

603

604

605

606

607

0.001 as determined by Student's t-test. Each dot represents value to form a single individual. Box shows average $\pm \mathrm{SD}$ of the values. $(\mathrm{N}, \mathrm{O})$ Derived predictions from the best-fit models retained in Casp1p20 (N) and IL-18 (O) longitudinal analyses; IL18 Model $(\mathrm{O})$ comprises variation in the intercept among patients' groups: Death (Red), Critical/Recovery (orange) and Mild/Recovery (blue).

Fig. S1. Cytokine production in COVID-19 patients. Cytokine concentration in the serum control individuals (CT, $\mathrm{n}=45$ ) and COVID-19 patients (COVID-19 P, $\mathrm{n}=92$; all tested positive using RT-PCR). IL-10 (A), IL-4 (B), IFN- $\gamma$ (C), TNF- $\alpha$ (D) and IL17A (E) were measured by CBA. Data are shown as Log10-transformed concentrations in $\mathrm{pg} / \mathrm{mL} .{ }^{* *} P<0.01$ and ${ }^{* * *} P<0.001$ as determined by Student's $\mathrm{t}$ test. Each dot represents the value form a single individual. Box show average $\pm \mathrm{SD}$ of the values.

\section{Fig. S2. Association of inflammasome activation with clinical characteristics and} comorbidities. (A) Matrix correlation of Casp1p20 and IL-18 levels in the serum of COVID-19 patients at the hospitalization day with clinical parameters and comorbidities. (B-S) Levels of Casp1p20 (B, D, F, H, J, L, N, P, R) and IL-18 (C, E, $\mathrm{G}, \mathrm{I}, \mathrm{K}, \mathrm{M}, \mathrm{O}, \mathrm{Q}, \mathrm{S}$ ) in patients with clinical parameters such as cultivable bacteria in the blood $(B, C)$, nephropathy $(D, E)$, obesity $(F, G)$, gender $(H, I)$, cerebrovascular accident (J, K), pneumopathy $(\mathrm{L}, \mathrm{M})$, immunodeficiency $(\mathrm{N}, \mathrm{O})$ and neoplasia $(\mathrm{P}, \mathrm{Q})$ and smoking (R, S). The levels of Casp1p20 and IL-18 were measured by ELISA and are shown as Log10-transformed concentrations in $\mathrm{pg} / \mathrm{mL} . * * P<0.01$ as determined 
medRxiv preprint doi: https://doi.org/10.1101/2020.08.05.20168872; this version posted August 6, 2020. The copyright holder for this preprint (which was not certified by peer review) is the author/funder, who has granted medRxiv a license to display the preprint in It is made available under a CC-BY-NC-ND 4.0 International license

608 by Student's $t$ test. Each dot represents value form a single individual. Box show

609 average \pm SD of the values.

610

611 Table S1 - Demographic and clinical characteristics of COVID-19

612 patients.

613

614

615 
medRxiv preprint doi: https://doi.org/10.1101/2020.08.05.20168872; this version posted August 6,2020 . The copyright holder for this preprint (which was not certified by peer review) is the author/funder, who has granted medRxiv a license to display the preprint in It is made available under a CC-BY-NC-ND 4.0 International license.

616

617 Table S1: COVID-19 patient characteristics

\begin{tabular}{|c|c|c|}
\hline \multicolumn{2}{|c|}{ Demographics } & \multirow[t]{2}{*}{$\%$} \\
\hline Number & 124 & \\
\hline Age (years) & $59.25 \pm 18.01$ & \\
\hline Female & $\overline{50}$ & $40 \%$ \\
\hline \multicolumn{3}{|c|}{ Comorbidities } \\
\hline Hypertension & 61 & $49 \%$ \\
\hline Obesity & 61 & $49 \%$ \\
\hline Diabetes & 46 & $37 \%$ \\
\hline History of smoking & 33 & $26 \%$ \\
\hline Heart disease & 23 & $18 \%$ \\
\hline Lung disease & 20 & $16 \%$ \\
\hline Kidney disease & 13 & $10 \%$ \\
\hline Cancer & 11 & $8 \%$ \\
\hline History of stroke & 9 & $7 \%$ \\
\hline Immunodeficiency & 6 & $4 \%$ \\
\hline Autoimmune diseases & 2 & $1 \%$ \\
\hline
\end{tabular}

\section{Laboratorial findings}

\begin{tabular}{lc} 
CRP $(\mathrm{mg} / \mathrm{dL})^{*}$ & $12.55 \pm 8.95$ \\
D-Dimers $(\mu \mathrm{g} / \mathrm{mL})^{* *}$ & $2.47 \pm 2.59$ \\
LDH $(\mathrm{U} / \mathrm{L})^{\#}$ & $565.147 \pm 325.9$ \\
Ferritin $(\mathrm{ng} / \mathrm{mL})^{\&}$ & $1225.07 \pm 1762.9$ \\
Haemoglobin $(\mathrm{g} / \mathrm{dL})$ & $12.31 \pm 2.34$ \\
Neutrophils $\left(\mathrm{cell} / \mathrm{mm}^{3}\right)$ & $6728.443 \pm 3903.57$ \\
Lymphocytes $\left(\mathrm{cell} / \mathrm{mm}^{3}\right)$ & $1307.37 \pm 789.1$ \\
Platelets (count $\left./ \mathrm{mm}^{3}\right)$ & $253426.2 \pm 111616.3$ \\
\hline
\end{tabular}

\begin{tabular}{lcc}
\hline \multicolumn{2}{c}{ Medications } & \\
Heparin & 112 & $90 \%$ \\
Antibiotics & 110 & $88 \%$ \\
Glucocorticoids & 58 & $46 \%$ \\
Oseltamivir & 56 & $45 \%$ \\
Antimalarial & 45 & $36 \%$ \\
\hline \multicolumn{2}{c}{ Respiratory status } \\
Mechanical ventilation & 56 & $45 \%$ \\
$\mathrm{Nasal}^{-c a n n u l a}$ oxygen & 111 & $89 \%$ \\
$\mathrm{pO}_{2}$ & $77.77 \pm 29.17$ & \\
$\mathrm{SatO}_{2}$ & $93.37 \pm 5.72$ \\
\end{tabular}

$618{ }^{*}$ CRP: C-reactive protein (Normal value $<0.5 \mathrm{mg} / \mathrm{dL}$ ); ${ }^{* *} D$-dimers $\left(N V<0.5 \mu \mathrm{g} / \mathrm{mL}\right.$ ); ${ }^{*} \mathrm{LDH}$ : lactate

619 dehydrogenase (Normal range: 120-246 U/L); ${ }^{\&}$ Ferritin (NR: 10-291 $\mathrm{ng} / \mathrm{mL}$ ) 
Figure 1. Rodrigues et al.

A

\section{Monocytes}

PAM3Cys Mock

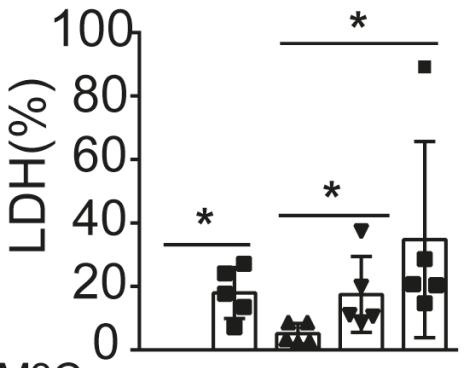
SARS-CoV-2

Nigericin
B Monocytes

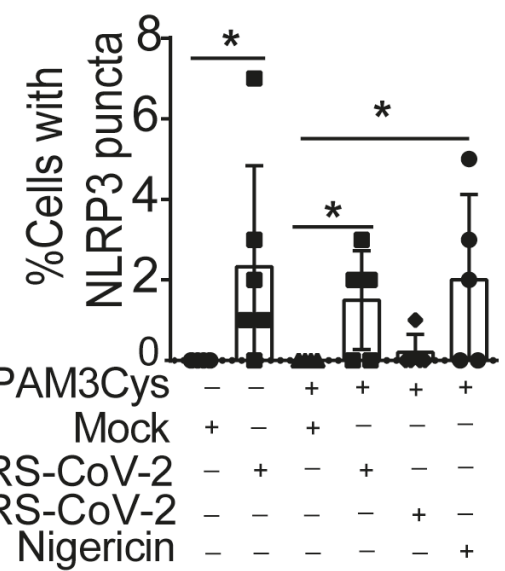

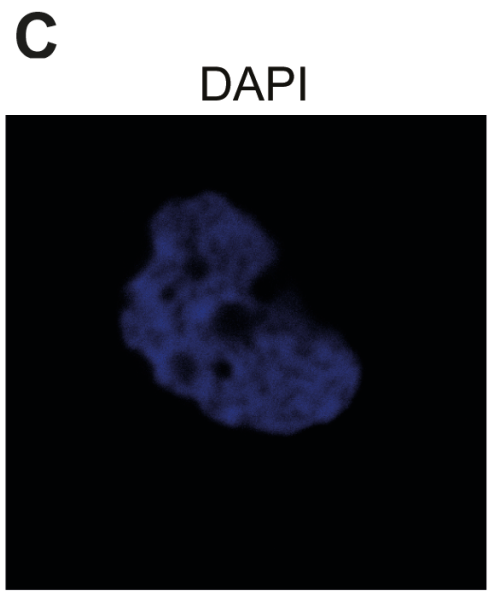

anti-dsRNA
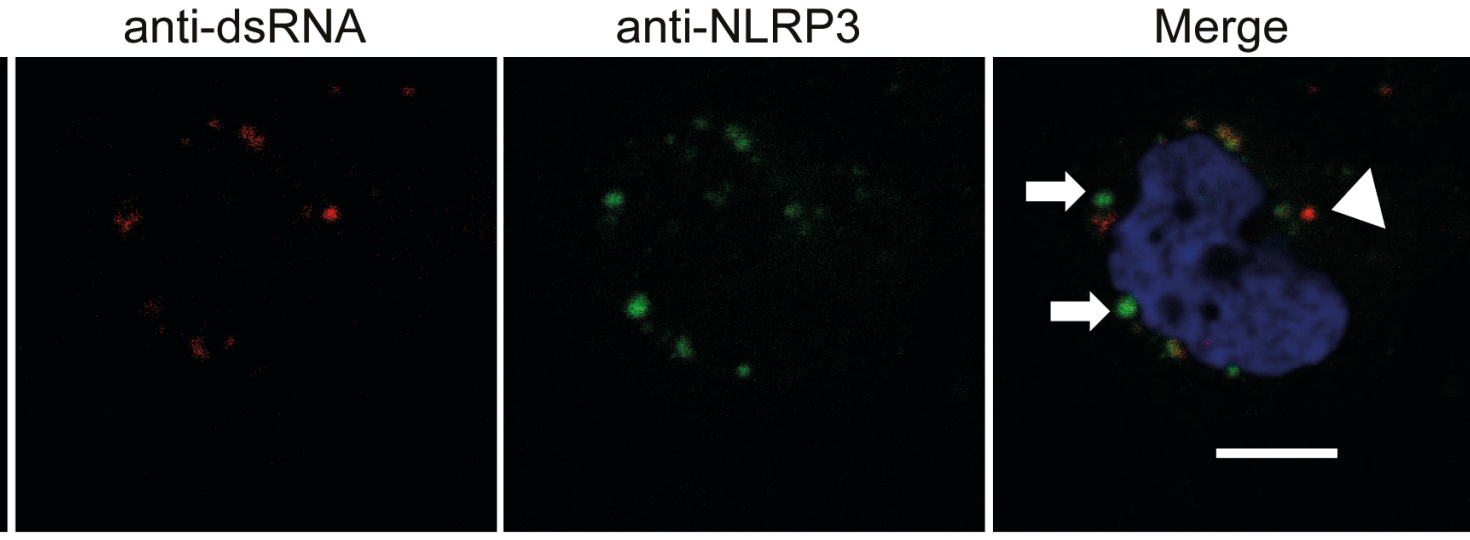

D

Monocytes

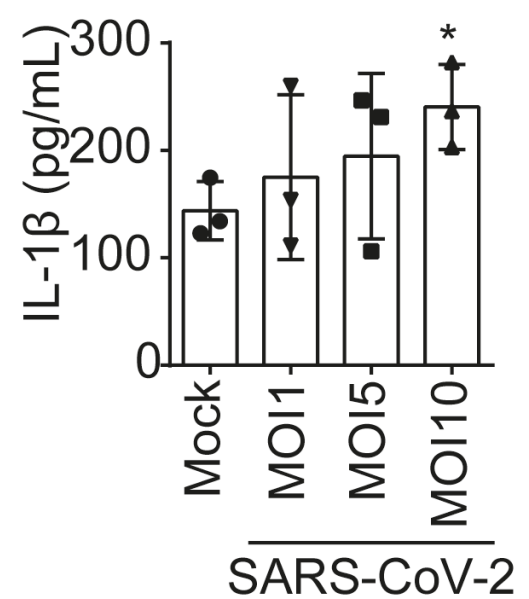

E Monocytes

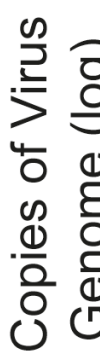

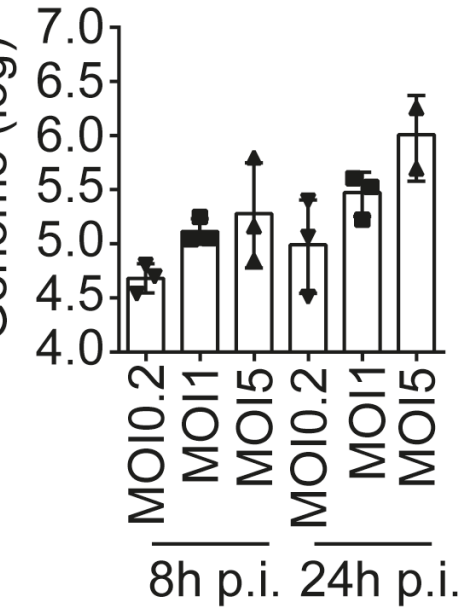

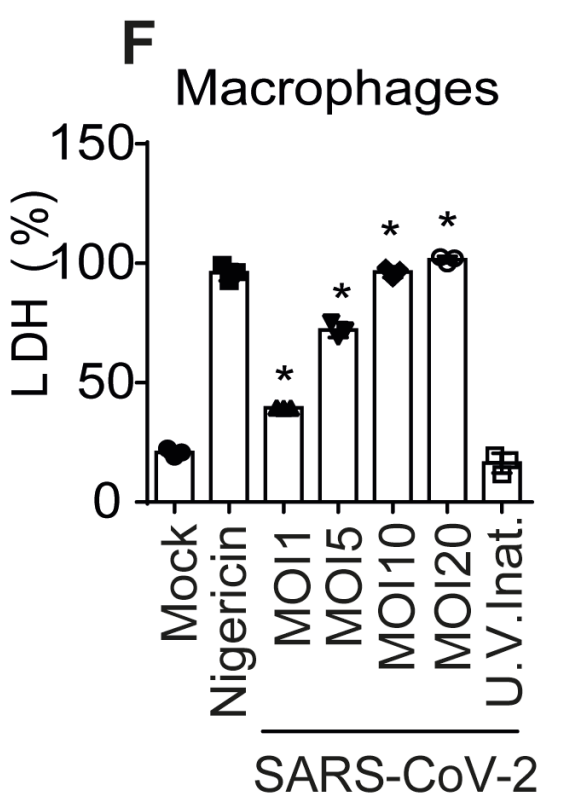


Figure 4. Rodrigues et al.
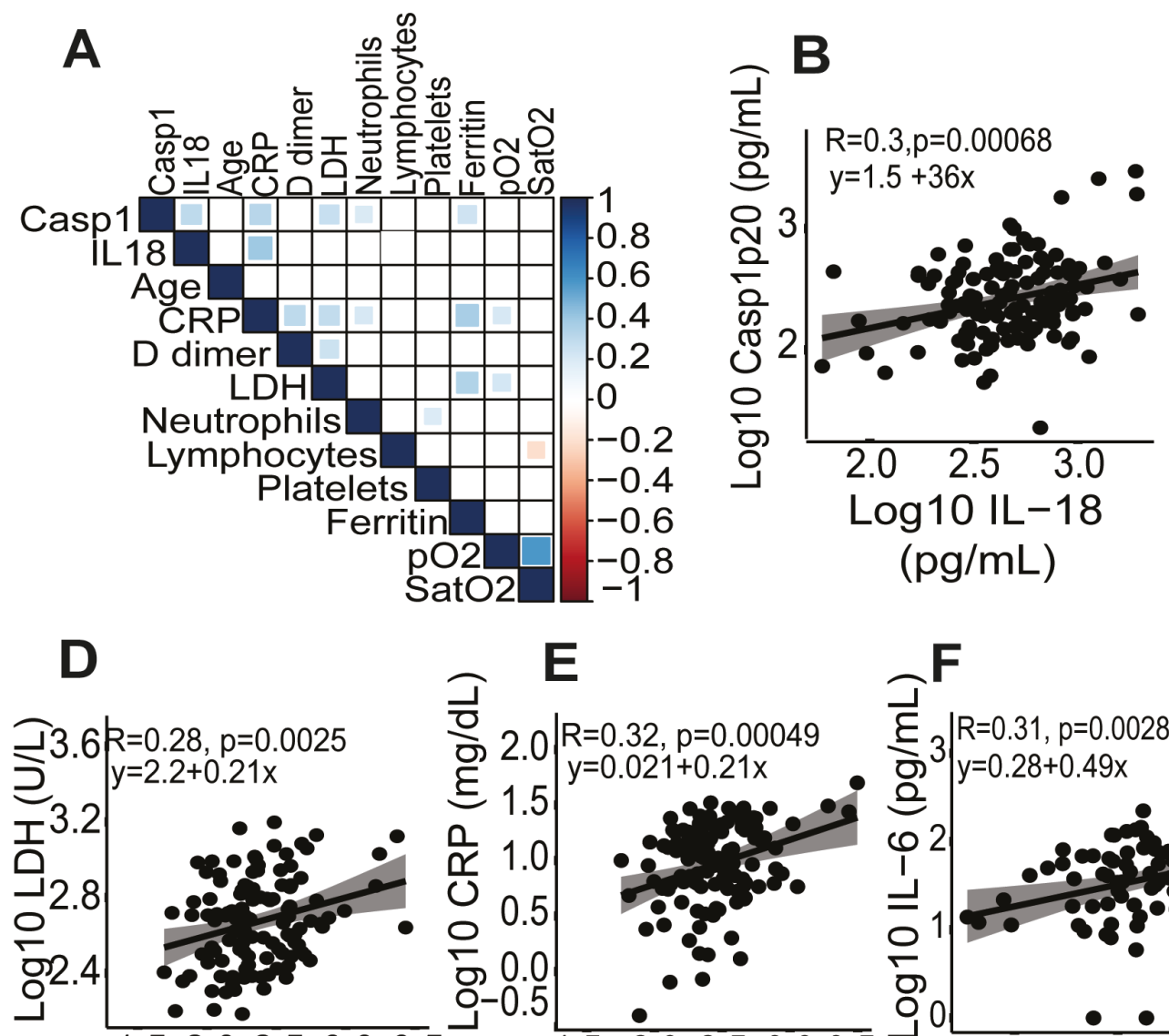

1.52 .02 .53 .03 .5 Log10 Casp1p20 $(\mathrm{pg} / \mathrm{mL})$

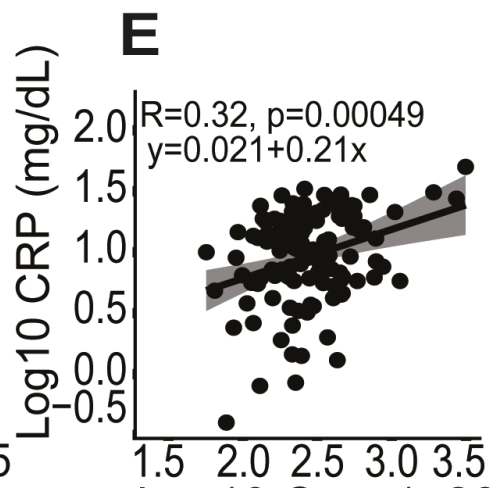
Log10 Casp1p20 $(\mathrm{pg} / \mathrm{mL})$

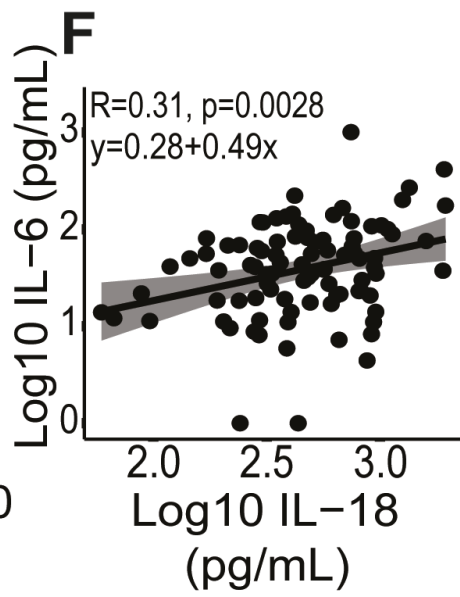

G
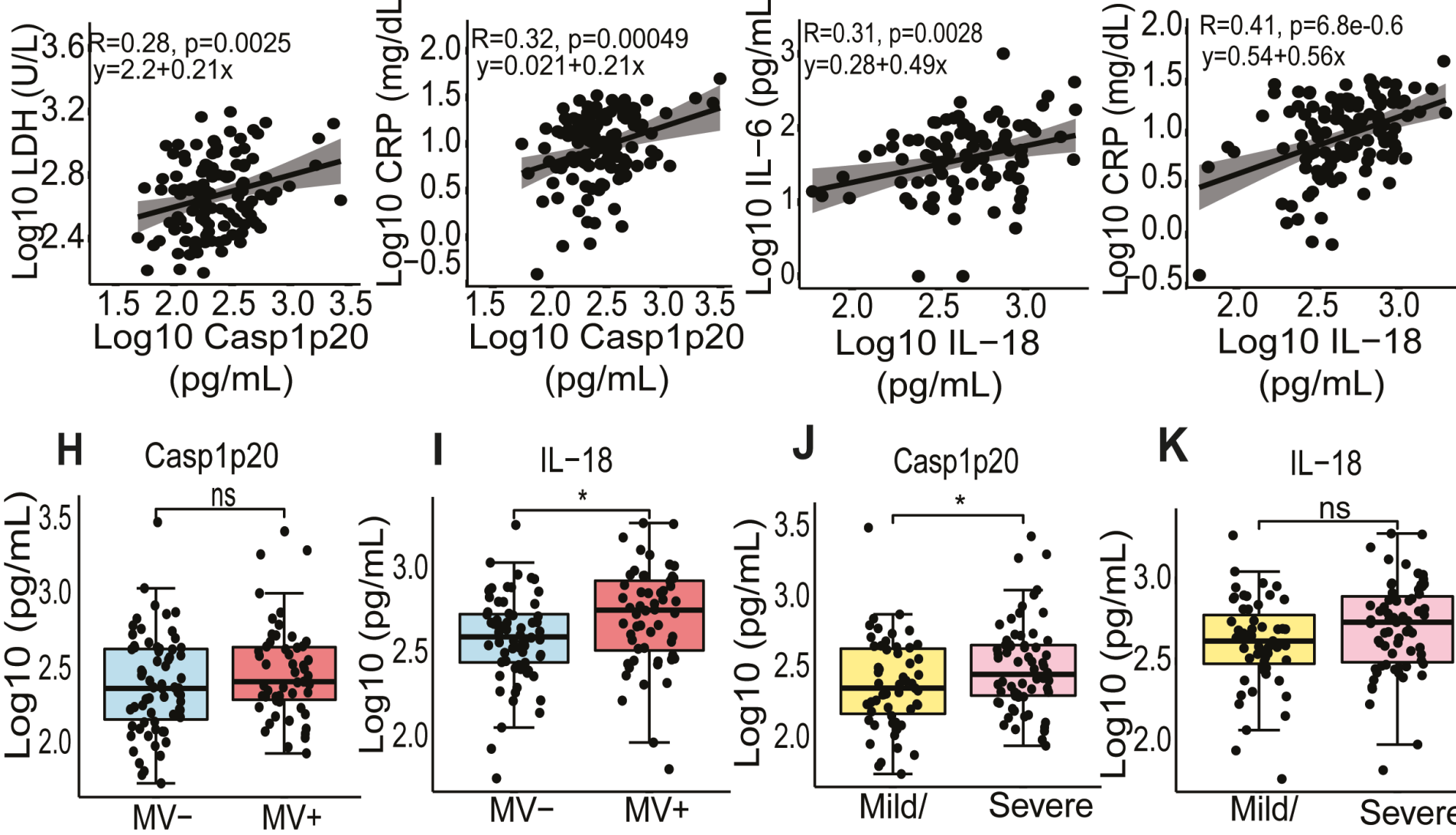

I IL-18

$\mathbf{J}$

Casp1p20
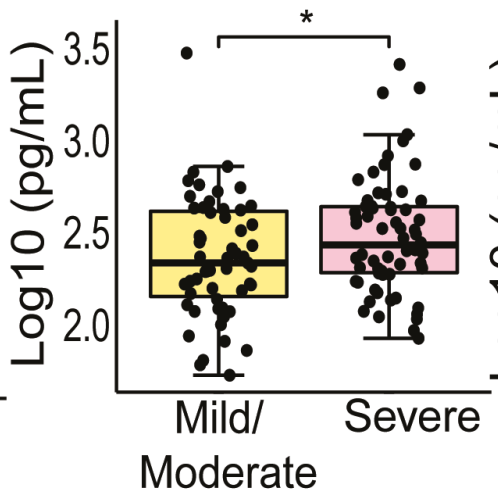

K

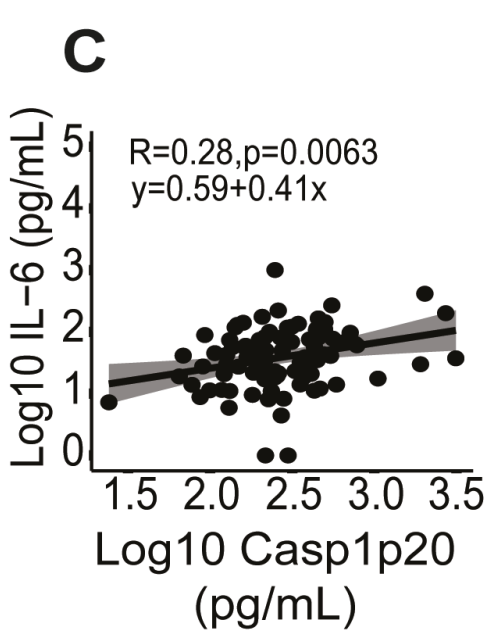

$(\mathrm{pg} / \mathrm{mL})$
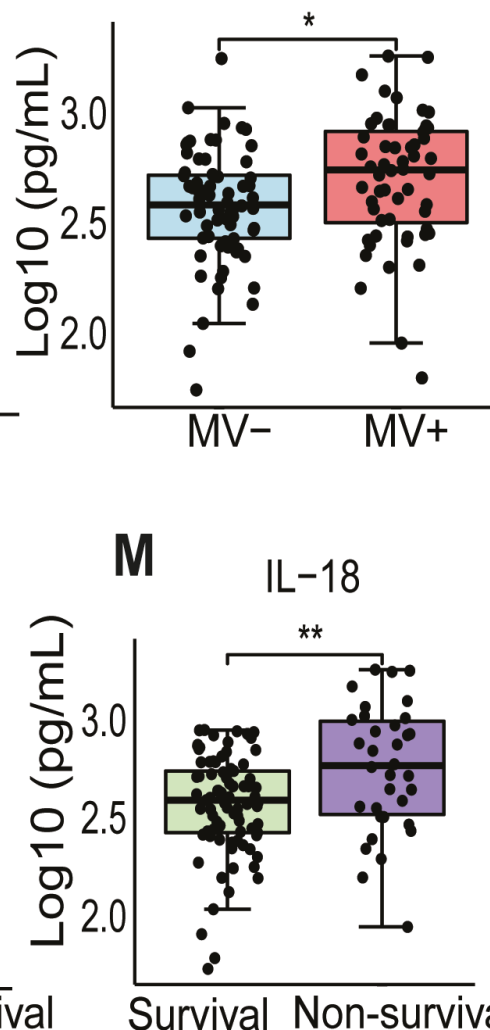

M IL-18

N
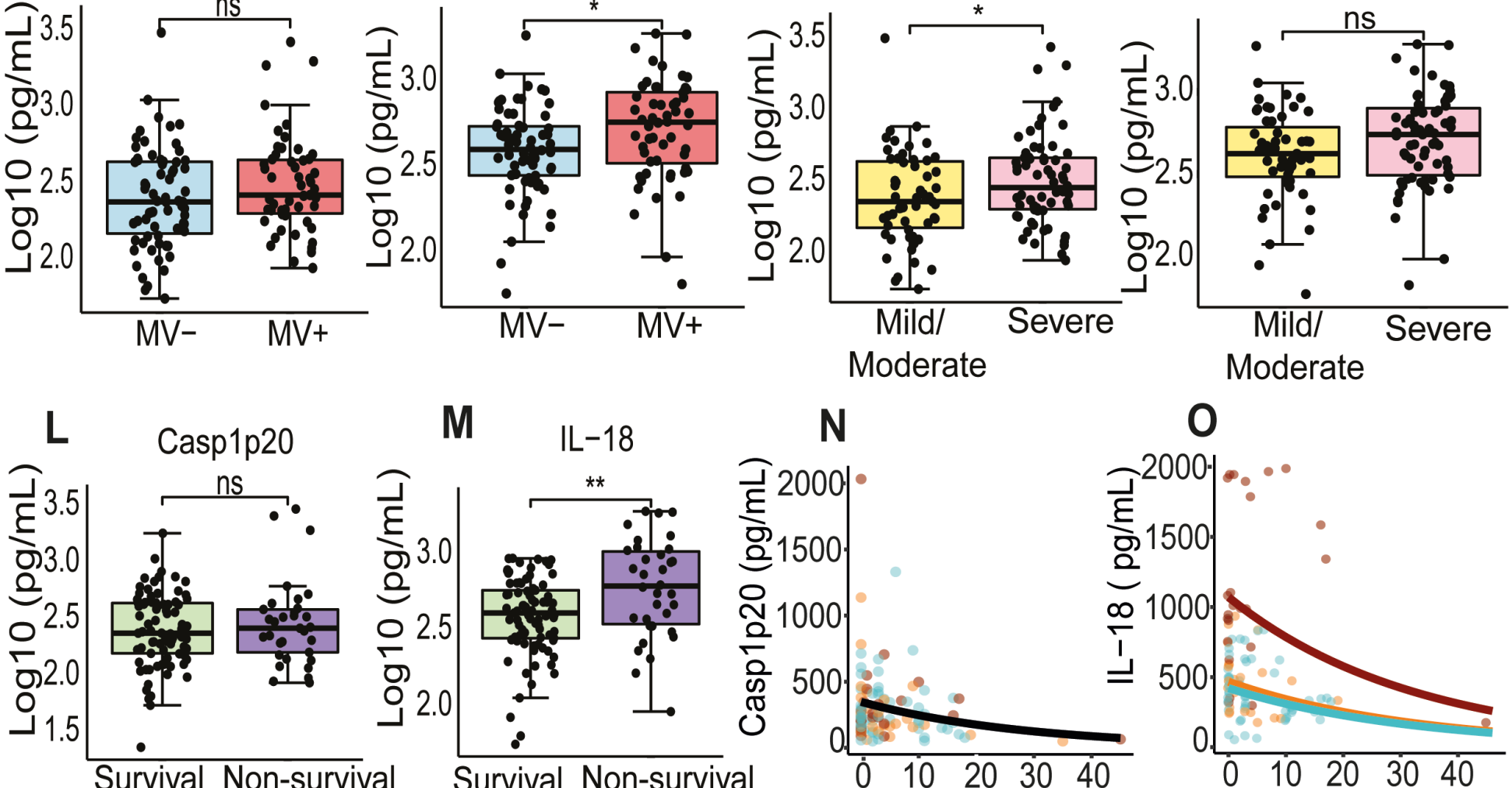

Survival Non-survival

Survival Non-survival
0

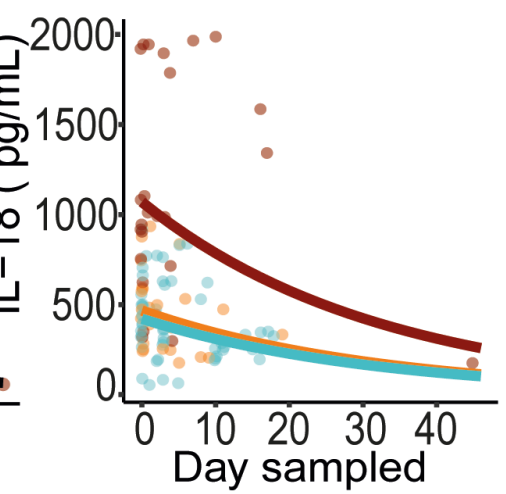


Fig. S1. Rodrigues et al.
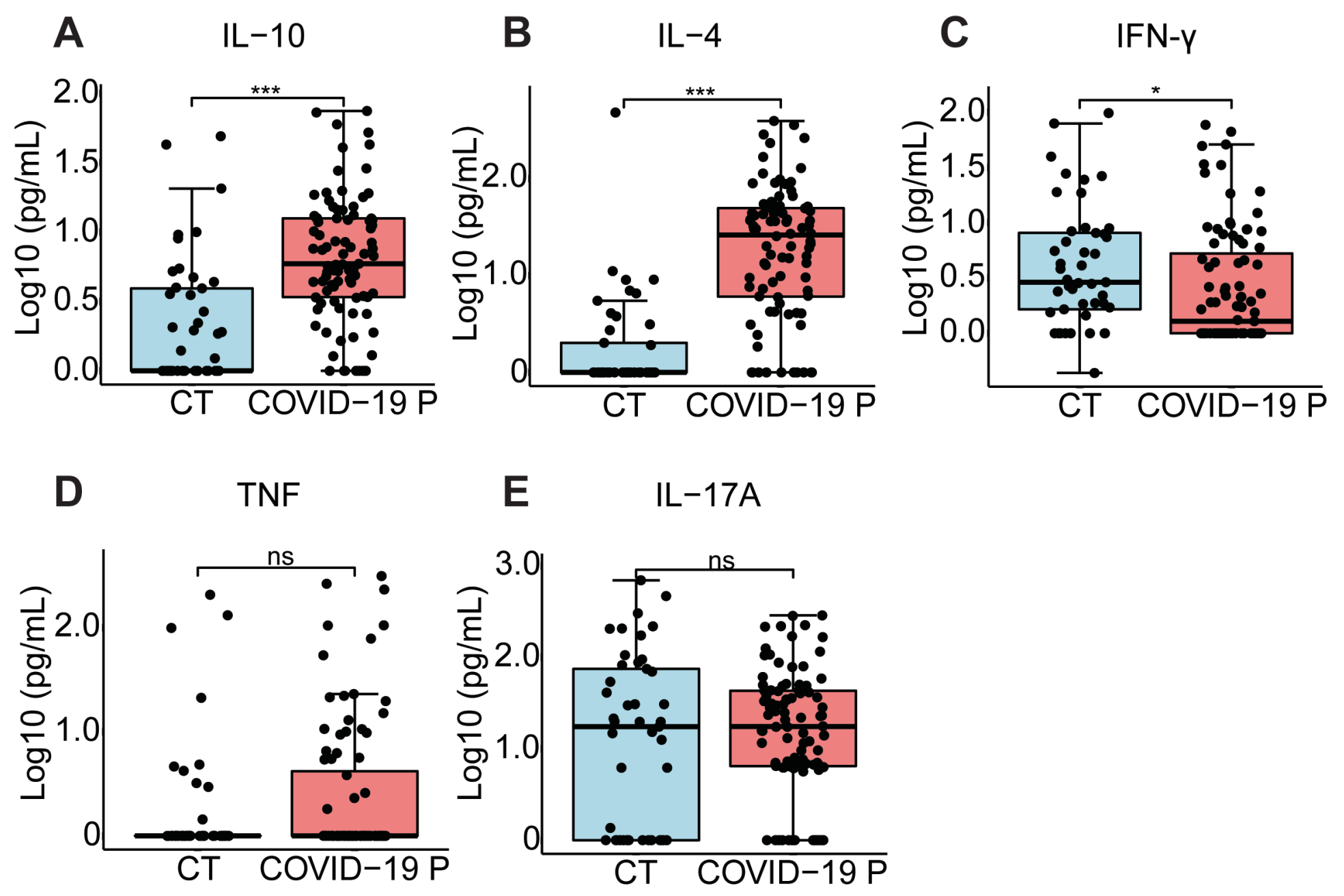


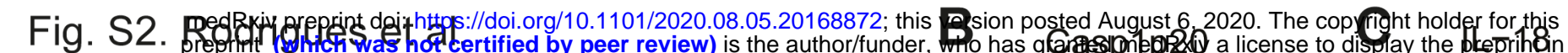

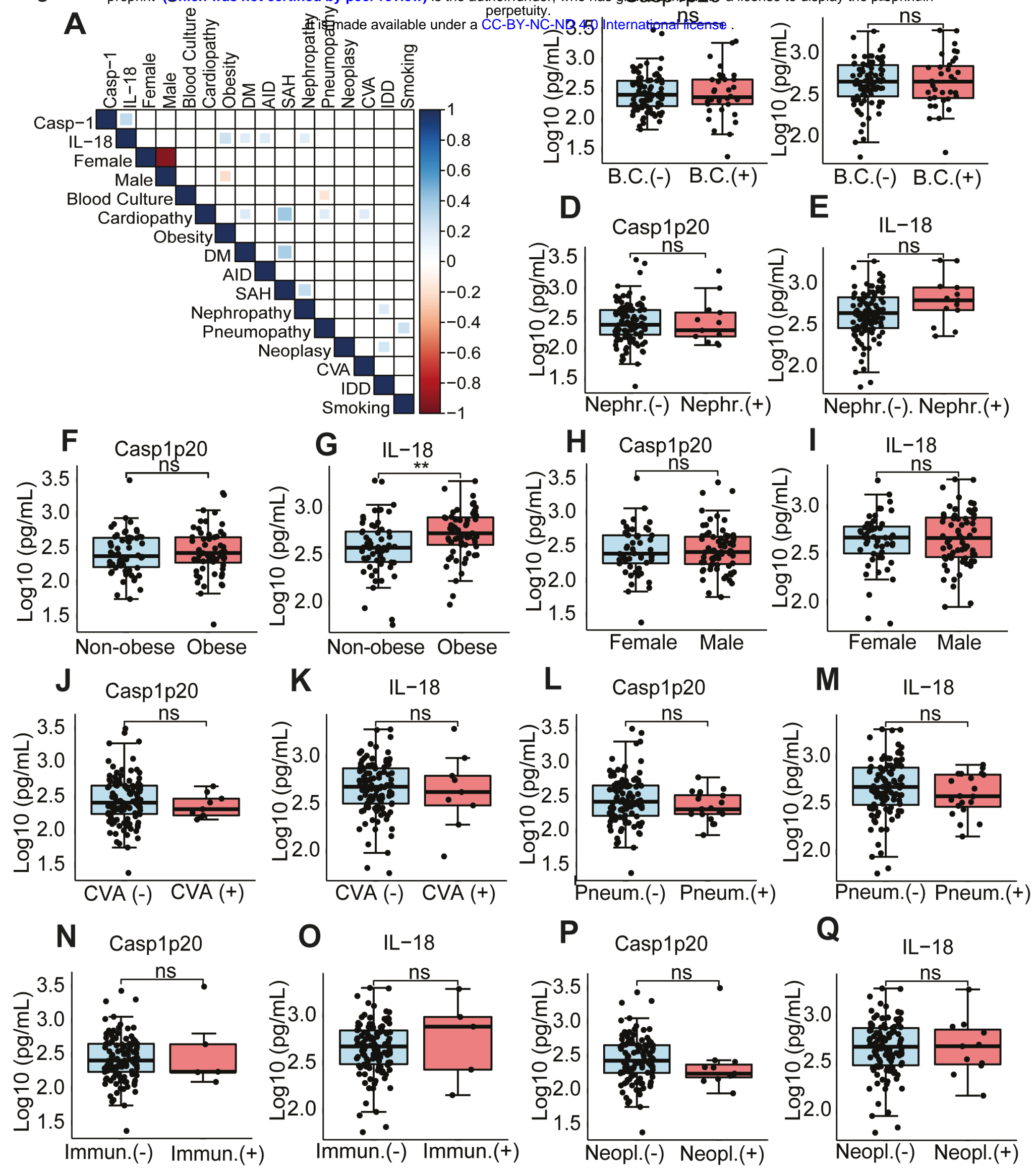

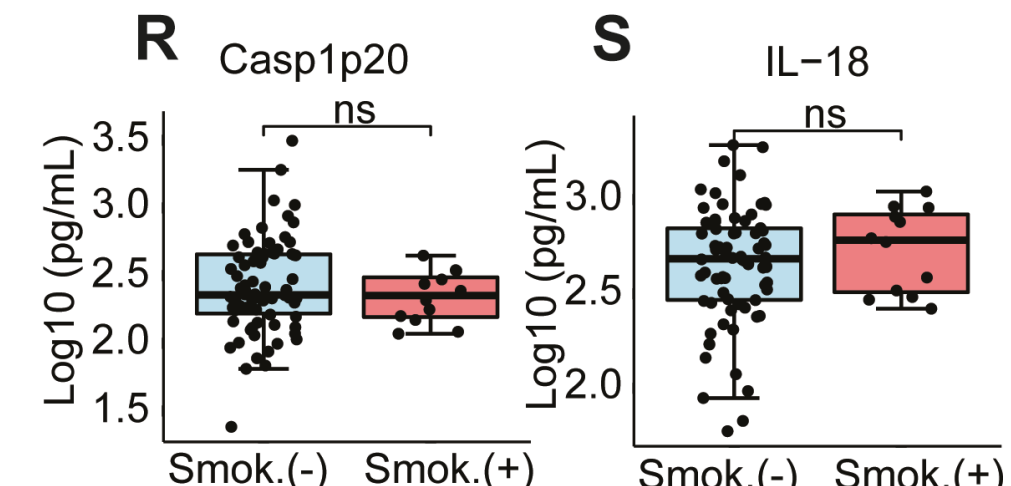

Smok.(-) Smok.(+)
M

Q 